\title{
Influence factors on the temperature field in a mass concrete
}

\author{
Nikolay Aniskin and Trong-Chuc Nguyen* \\ Moscow State University of Civil Engineering, Yaroslavskoe shosse, 26, Moscow, 129337, Russia
}

\begin{abstract}
In construction practice of concrete mass needs a large amount of concrete. Due to the small surface area to volume ratio, the concrete mass is often happening thermal cracking caused by the release of heat during the hydration of the cement. The causes of thermal cracking in concrete mass are complex but the main reason is the increase in temperature in the concrete structure. Provide measures to control the maximum temperature concrete mass is very absolutely necessary. A finite element model of the concrete mass was established by the software Midas civil, the temperature field in the concrete mass has been determined and a mathematical model was created that adequately describes the influence factors on the temperature field in a concrete mass such as unit cement content, cement maximum heat released, the placing temperature of concrete and the water temperature in order to determine the optimal parameters.
\end{abstract}

\section{Introduction}

The most popular in the practice in the building of massive concrete structures consists of dams, bridges, foundations, etc [1,2]. In the process of building of massive concrete structures, the thermal stress generated by the hydration of cement heat may cause cracks in concrete structures at early ages. Because of the cracks in concrete structures resulting in reduced durability, they must be controllable [3-5].

According to research results [6-9], the temperature distribution in the concrete mass and its evolution over time depend on the following factors:

- Concrete placement schedule,

- The thickness of the laid concrete layer,

- Unit cement content,

- The placing temperature of concrete,

- Cement maximum heat released,

- Size concrete blocks,

- Ambient air temperature,

- The use of cooling systems in concrete mass, etc.

In this paper, using the Midas Civil computer programs has been determined maximum temperatures inside of the concrete blocks, and created a mathematical model that

\footnotetext{
* Corresponding author: ntchuc.mta198@gmail.com
} 
adequately describes the effect of factors on the temperature field in a concrete mass such as unit cement content, cement maximum heat released, the placing temperature of concrete and the water temperature in order to determine the optimal parameters.

\section{Materials and methods}

\subsection{Subject of study}

In this paper, the object of research is a mass concrete of size $10 \mathrm{~m} \times 20 \mathrm{~m} \times 3 \mathrm{~m}$. Because a mass concrete has symmetry properties, in order to reduce the number of calculations so one-half of it was analyzed. The type and dimensions of the investigated concrete block is shown in Figure 1. The climate of this region was taken the air temperature $26.5^{\circ} \mathrm{C}$, temperatures of soil $25^{\circ} \mathrm{C}$. The thermophysical characteristics of the concrete massif and the foundation for explanatory variables are listed in Table 1.

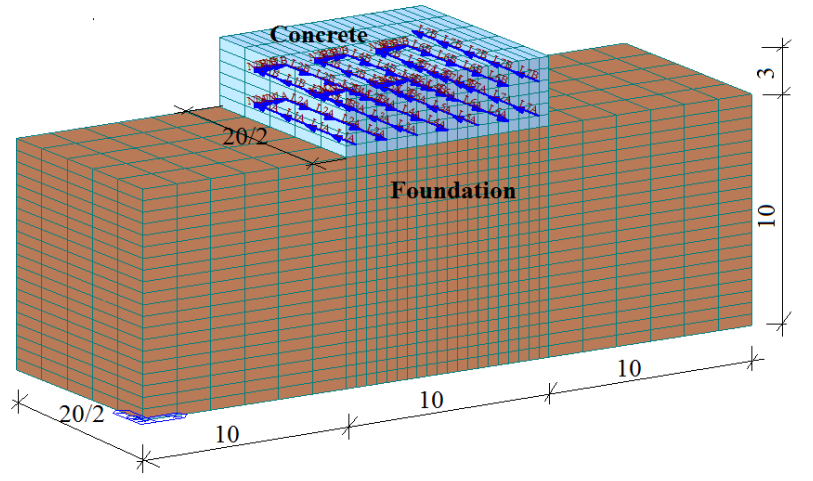

Fig. 1. 3D FE mesh model of a mass concrete, unit $\mathrm{m}$

Table 1. Thermophysical characteristics of the concrete mass and the foundation.

\begin{tabular}{|l|c|c|}
\hline \multicolumn{1}{|c|}{ Thermophysical characteristics } & Concrete & Foundation \\
\hline Thermal conductivity, $\left(\mathrm{W} / \mathrm{m} .{ }^{\circ} \mathrm{C}\right)$ & 2.65 & 1.98 \\
\hline Specific heat capacity, $\left(\mathrm{J} / \mathrm{kg} .{ }^{\circ} \mathrm{C}\right)$ & 950 & 850 \\
\hline Density, $\left(\mathrm{kg} / \mathrm{m}^{3}\right)$ & 2400 & 1800 \\
\hline Surface heat transfer coefficient, $\left(\mathrm{W} / \mathrm{m}^{2} .{ }^{\circ} \mathrm{C}\right)$ & 12.0 & 13.5 \\
\hline Thermal expansion coefficient $\left(1 /{ }^{\circ} \mathrm{C}\right)$ & $1.0 \times 10^{-5}$ & $1.0 \times 10^{-5}$ \\
\hline Elastic modulus $\left(\mathrm{N} / \mathrm{m}^{2}\right)$ & $2.7 \times 10^{10}$ & $1.8 \times 10^{10}$ \\
\hline Poisson's ratio & 0.20 & 0.28 \\
\hline
\end{tabular}

The development of the temperature field in the concrete mass to affect by a large number of factors, such as the ambient temperature and construction technology. In the present work, the method of planning an experiment is used in order to build a mathematical model $[10,11]$.

The major factors affecting the maximum temperature were considered:

$\mathrm{X}_{1}(\mathrm{C})$ - the unit cement content is from 200 to $450, \mathrm{~kg} / \mathrm{m}^{3}$;

$\mathrm{X}_{2}\left(\mathrm{Q}_{\max }\right)$ - the maximum heat cement is from 120 to $350, \mathrm{~kJ} / \mathrm{kg}$;

$\mathrm{X}_{3}\left(\mathrm{t}_{\mathrm{pl}}\right)$ - the placing temperature is from 10 to $25,{ }^{\circ} \mathrm{C}$;

$\mathrm{X}_{4}\left(\mathrm{t}_{\mathrm{w}}\right)$ - the water temperature is from 8 to $16,{ }^{\circ} \mathrm{C}$. 
It is assumed that the response function in the experimental region (1) can be approximated by a polynomial [12]:

$$
\begin{aligned}
Y_{i}=b_{o}+b_{1} X_{1}+ & b_{2} X_{2}+b_{3} X_{3}+b_{4} X_{4}+b_{12} X_{1} X_{2}+b_{13} X_{1} X_{3}+b_{14} X_{1} X_{4}+b_{23} X_{2} X_{3}+b_{24} X_{2} X_{4}+ \\
& +b_{34} X_{3} X_{4}+b_{1234} X_{1} X_{2} X_{3} X_{4}
\end{aligned}
$$

The number of necessary experiments $\mathrm{N}$ in the planning was determined by the formula (2):

$$
N=2^{k}+1,
$$

where: $\mathrm{k}$ - the number of input factors; 1 - the number of repeating the experiments in the center; therefore $\mathrm{N}=2^{4}+1=17$.

Also, equation (1) is called the regression equation in which, $b_{i}-$ coefficients determined using the method of least squares.

$$
b_{i}=\frac{\sum_{j=1}^{16} y_{i} X_{i j}}{16}
$$

In order to check the adequacy of a mathematical model obtained, another experiment was performed with factors in the center levels (equal to the average values of the factors between their minimum and maximum values).

Typical values for the radius and speed of the pipe $r_{0}=3.0 \mathrm{~cm}, u=50 \mathrm{~cm} / \mathrm{s}$, the distribution of the cooling pipes was designed to be $1.5 \mathrm{~m} \times 1.5 \mathrm{~m}$ (diagram according to the vertical and horizontal), the time of water cooling was used immediately after 6 hours the completion of concrete pouring and lasted about 7 days to reduce the maximum temperature in the concrete mass. In this study, the thermal properties of the cooling water is given in Table 2. Distribution of cooling pipes is shown in Figure 1.

Table 2. Thermophysical characteristics of of the cooling water.

\begin{tabular}{|l|c|}
\hline \multicolumn{1}{|c|}{ Thermophysical characteristics } & Value \\
\hline Thermal conductivity, $\left(\mathrm{W} / \mathrm{m} .{ }^{\circ} \mathrm{C}\right)$ & 0.16 \\
\hline Specific heat capacity, $\left(\mathrm{J} / \mathrm{kg} .{ }^{\circ} \mathrm{C}\right)$ & 4200 \\
\hline Density, $\left(\mathrm{kg} / \mathrm{m}^{3}\right)$ & 1000 \\
\hline Surface heat transfer coefficient, $\left(\mathrm{W} / \mathrm{m}^{2} \cdot{ }^{\circ} \mathrm{C}\right)$ & 282 \\
\hline
\end{tabular}

\subsection{The finite element method for heat transfer problems}

Based on the law of energy balance, the Fourier equation determining the heat transfer for concrete structures and water flowing through a pipe can be seen by formulas (4) and (5), which include process temperature increases by chemical reaction of cement and water and the heat loss due to forced cooling [13-16].

$$
k_{c} \nabla^{2} T_{c}+Q_{c}=\rho_{c} c_{c} \frac{\partial T_{c}}{\partial t},
$$




$$
\rho_{\mathrm{w}} c_{\mathrm{w}}\left(\frac{\partial T_{\mathrm{w}}}{\partial t}+\vec{u} \nabla T_{\mathrm{w}}\right)=k_{\mathrm{w}} \nabla^{2} T_{\mathrm{w}},
$$

Where: T - temperature, ${ }^{\circ} \mathrm{C} ; \mathrm{k}$ - thermal diffusivity, $\mathrm{m}^{2} / \mathrm{s} ; \mathrm{c}-$ specific heat, $\mathrm{J} / \mathrm{kg} .{ }^{\circ} \mathrm{C} ; \rho$ density, $\mathrm{kg} / \mathrm{m}^{3} ; \mathrm{t}$ - age of concrete, day; $\mathrm{Q}_{\mathrm{c}}$ - heat of hydration of the cement during hydration, $\mathrm{kJ} / \mathrm{m}^{3} ; \mathrm{c}$, w represent respectively concrete and water.

Boundaries in our heat problem consist of the thermal transfer boundary, insulation boundary and fixed thermal boundary. Because the thermal transfer boundary mainly affects the surface of the concrete mass, in this model convection is used [17].

The total amount of heat generation due to the thermal hydration of cement per unit volume can be obtained from the equation $[18,19]$ :

$$
Q_{c}(t)=Q_{\max }\left[1-\left(1+A_{20} t\right)^{-n}\right]
$$

Where: $\mathrm{Q}_{\max }=\mathrm{q}_{\mathrm{v}} \mathrm{C}$ - the heat of hydration of the cement during process hydration, $\mathrm{kJ} / \mathrm{m}^{3} ; \mathrm{C}$ - the unit cement content, $\mathrm{kg} / \mathrm{m}^{3} ; \mathrm{A}_{20}$ - the coefficient of heat dissipation speed depends on the hardening temperature of $\mathrm{T}=20^{\circ} \mathrm{C}, \mathrm{A}_{20}=0.012-0.015 \mathrm{~h}^{-1} ; \mathrm{n}$ - constant coefficients, dependent on the placing temperature of concrete mixture, $n=0.83$ [20].

Based on the principles of finite element, performing the equations of heat-fluid elements, which satisfy the heat conduction equation and boundary conditions can be written as (7):

$$
[C]\left\{\frac{\partial T}{\partial t}\right\}+[K]\{T\}=Q,
$$

Where: $[\mathrm{K}]$ - heat conduction matrix of the heat-fluid element; $\{\mathrm{T}\}$ - temperature vector; $[C]$ - specific heat matrix; $\{\partial \mathrm{T} / \partial \mathrm{t}\}$ - variable temperature rate vector; and $\{\mathrm{Q}\}$ - node heat transfer rate vector.

\subsection{Determining the maximum allowable temperature in a mass concrete}

According to the study [21], it is determined that the maximum allowable temperature in a mass concrete depends on the concrete mix, the size of the concrete block, the restraint coefficient...etc is given by equation (8).

$$
\left[T_{c}^{\max }\right]=T_{c \text { oper }}^{a}+\left[\Delta T_{c}^{\max }\right]
$$

Where: $T_{c \text { oper }}^{a}$ - the average temperature of mass concrete during operation; $\left[\Delta T_{c}^{\max }\right]-$ the allowable temperature difference of mass concrete during construction are given by equations (9), (10).

$$
\begin{aligned}
& {\left[\Delta T_{c}^{\max }\right]=\left[\Delta T_{c}^{a}\right] \kappa,} \\
& {\left[\Delta T_{c}^{a}\right]=\frac{\varepsilon}{\alpha k_{1} k_{2} k_{3}}}
\end{aligned}
$$

Where: $\mathrm{k}$ - the transition coeffcient from the average temperature in the mass concrete during heat evolution period $(\mathrm{k}=1.3 \div 1.5) ; \varepsilon$ - the limit compliance mass concrete; $\alpha$ - 
linear thermal expansioncoefficient of concrete; $\mathrm{k}_{1}$ - crushing factor (average); $\mathrm{k}_{2}$ relaxation factor (average); $\mathrm{k}_{3}$ - factor of crack formation ignorance.

\section{Results}

In all the experiments planning, the temperature field in the concrete mass was calculations by using the Midas civil software (based on the finite element method). The planning matrix of the experiment and the levels of factors and maximum temperatures of a mass concrete depend on building conditions are given in Table 3.

Simulation mathematical model of maximum temperature in the concrete mass was obtained from the results of calculations of the maximum temperature of concrete mass. We can see equation (11).

$$
\mathrm{T}_{\max }=39.85+9.19 \mathrm{X}_{1}+11.68 \mathrm{X}_{2}+3.97 \mathrm{X}_{3}+1.89 \mathrm{X}_{4}+4.70 \mathrm{X}_{1} \mathrm{X}_{2}
$$

From equation (11), we can note the following, all factors were considered to affect the value of the maximum temperature of the concrete structure. Maximum temperature in concrete mass is most dependent on factors: $X_{1}(C)$ - the unit cement content, $X_{2}\left(Q_{\max }\right)$ - the maximum heat cement, and $\mathrm{X}_{3}\left(\mathrm{t}_{\mathrm{pl}}\right)$ - the placing temperature. Analysis effect of two pairwise selected factors (assuming the remaining factors are zero) $\left(\mathrm{X}_{1}, \mathrm{X}_{2}\right),\left(\mathrm{X}_{1}, \mathrm{X}_{3}\right),\left(\mathrm{X}_{1}\right.$, $\left.\mathrm{X}_{4}\right),\left(\mathrm{X}_{2}, \mathrm{X}_{3}\right),\left(\mathrm{X}_{2}, \mathrm{X}_{4}\right)$, and $\left(\mathrm{X}_{3}, \mathrm{X}_{4}\right)$. The simpler equations of the influence of two factors on the temperature field in a concrete structure were obtained from equation (8) is given in Table 4. With the help of the Matlab program, nomograms were obtained for determining the maximum temperature in accordance with the simplified equations from Table 4.

Based on the tables (15.5), (15.6) of the study [21] and the average air temperature during the construction period, the maximum temperature allowed in the concrete obtained is $45.07^{\circ} \mathrm{C}$. Figure 2 shows these nomograms that used in order to assess the maximum temperature and optimal parameters to prevent crack formationof the concrete structure (the crossed region of the nomograms corresponding to the parameters causing cracks forming).

Table 3. Experiment planning matrix.

\begin{tabular}{|c|c|c|c|c|c|c|c|c|c|}
\hline \multirow[b]{2}{*}{ No } & \multirow[b]{2}{*}{$X_{1}$} & \multirow[b]{2}{*}{$\mathrm{X}_{2}$} & \multirow[b]{2}{*}{$X_{3}$} & \multirow[b]{2}{*}{$\mathrm{X}_{4}$} & \multicolumn{4}{|c|}{ The values of the factors } & \multirow{2}{*}{$\underset{{ }^{\circ} \mathrm{C}}{\mathrm{T}_{\max },}$} \\
\hline & & & & & $\begin{array}{c}\mathrm{X}_{1}, \\
\mathrm{~kg} / \mathrm{m}^{3}\end{array}$ & $\begin{array}{c}\mathrm{X}_{2}, \\
\mathrm{~kJ} / \mathrm{kg}\end{array}$ & $\begin{array}{c}\mathrm{X}_{3}, \\
{ }^{\circ} \mathrm{C}\end{array}$ & $\begin{array}{c}\mathrm{X}_{4}, \\
{ }^{\circ} \mathrm{C}\end{array}$ & \\
\hline 1 & -1 & -1 & -1 & -1 & 200 & 120 & 10 & 8 & 16.99 \\
\hline 2 & 1 & -1 & -1 & -1 & 450 & 120 & 10 & 8 & 26.55 \\
\hline 3 & -1 & 1 & -1 & -1 & 200 & 350 & 10 & 8 & 31.65 \\
\hline 4 & 1 & 1 & -1 & -1 & 450 & 350 & 10 & 8 & 59.53 \\
\hline 5 & -1 & -1 & 1 & -1 & 200 & 120 & 25 & 8 & 26.72 \\
\hline 6 & 1 & -1 & 1 & -1 & 450 & 120 & 25 & 8 & 34.97 \\
\hline 7 & -1 & 1 & 1 & -1 & 200 & 350 & 25 & 8 & 39.67 \\
\hline 8 & 1 & 1 & 1 & -1 & 450 & 350 & 25 & 8 & 67.55 \\
\hline 9 & -1 & -1 & -1 & 1 & 200 & 120 & 10 & 16 & 21.94 \\
\hline 10 & 1 & -1 & -1 & 1 & 450 & 120 & 10 & 16 & 30.95 \\
\hline 11 & -1 & 1 & -1 & 1 & 200 & 350 & 10 & 16 & 35.97 \\
\hline 12 & 1 & 1 & -1 & 1 & 450 & 350 & 10 & 16 & 63.45 \\
\hline 13 & -1 & -1 & 1 & 1 & 200 & 120 & 25 & 16 & 29.02 \\
\hline 14 & 1 & -1 & 1 & 1 & 450 & 120 & 25 & 16 & 38.18 \\
\hline 15 & -1 & 1 & 1 & 1 & 200 & 350 & 25 & 16 & 43.27 \\
\hline 16 & 1 & 1 & 1 & 1 & 450 & 350 & 25 & 16 & 71.15 \\
\hline $17 *$ & 0 & 0 & 0 & O & 325 & 235 & 17.5 & 12 & 39.50 \\
\hline
\end{tabular}


Table 4. The equations obtained from the relationship between the two factors.

\begin{tabular}{|c|c|c|}
\hline No & Factors & \multicolumn{1}{c|}{ Functions } \\
\hline 1 & $\mathrm{X}_{3}=0, \mathrm{X}_{4}=0,-1 \leq \mathrm{X}_{1} \leq 1 ;-1 \leq \mathrm{X}_{2} \leq 1$ & $\mathrm{~T}_{\max }=39.85+9.19 \mathrm{X}_{1}+11.68 \mathrm{X}_{2}+4.7 \mathrm{X}_{1} \mathrm{X}_{2}$ \\
\hline 2 & $\mathrm{X}_{2}=0, \mathrm{X}_{4}=0,-1 \leq \mathrm{X}_{1} \leq 1 ;-1 \leq \mathrm{X}_{3} \leq 1$ & $\mathrm{~T}_{\max }=39.85+9.19 \mathrm{X}_{1}+3.97 \mathrm{X}_{3}$ \\
\hline 3 & $\mathrm{X}_{2}=0, \mathrm{X}_{3}=0,-1 \leq \mathrm{X}_{1} \leq 1 ;-1 \leq \mathrm{X}_{4} \leq 1$ & $\mathrm{~T}_{\max }=39.85+9.19 \mathrm{X}_{1}+1.89 \mathrm{X}_{4}$ \\
\hline 4 & $\mathrm{X}_{1}=0, \mathrm{X}_{4}=0,-1 \leq \mathrm{X}_{2} \leq 1 ;-1 \leq \mathrm{X}_{3} \leq 1$ & $\mathrm{~T}_{\max }=39.85+11.68 \mathrm{X}_{2}+3.97 \mathrm{X}_{3}$ \\
\hline 5 & $\mathrm{X}_{1}=0, \mathrm{X}_{3}=0,-1 \leq \mathrm{X}_{2} \leq 1 ;-1 \leq \mathrm{X}_{4} \leq 1$ & $\mathrm{~T}_{\max }=39.85+11.68 \mathrm{X}_{2}+1.89 \mathrm{X}_{4}$ \\
\hline 6 & $\mathrm{X}_{1}=0, \mathrm{X}_{2}=0,-1 \leq \mathrm{X}_{3} \leq 1 ;-1 \leq \mathrm{X}_{4} \leq 1$ & $\mathrm{~T}_{\max }=39.85+3.89 \mathrm{X}_{3}+1.89 \mathrm{X}_{4}$ \\
\hline
\end{tabular}

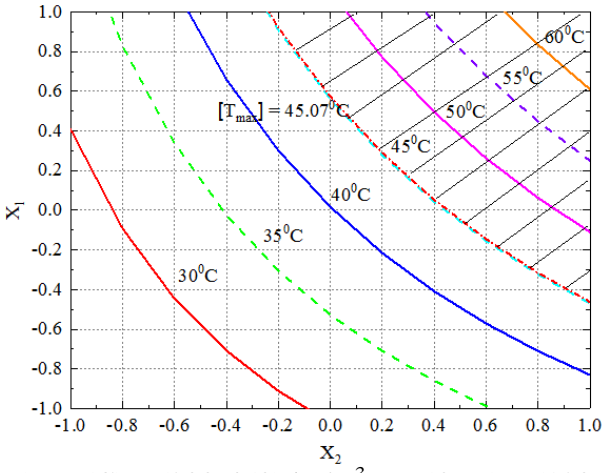

a) $X_{1}(C)=(200-450) \mathrm{kg} / \mathrm{m}^{3}, X_{2}\left(Q_{\max }\right)=(120-$ $350) \mathrm{kJ} / \mathrm{kg}$.

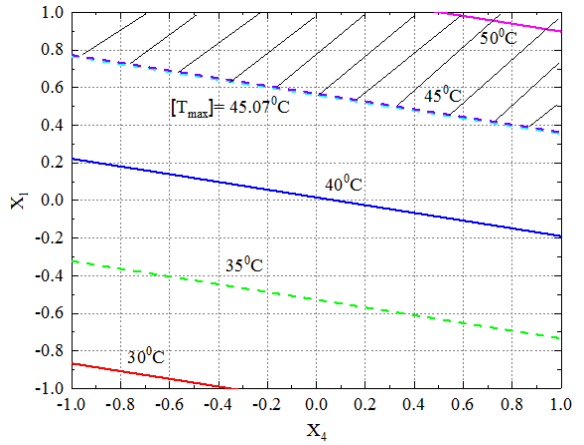

c) $\mathrm{X}_{1}(\mathrm{C})=(200-450) \mathrm{kg} / \mathrm{m}^{3}, \mathrm{X}_{4}\left(\mathrm{t}_{\mathrm{w}}\right)=(8-16)^{\circ} \mathrm{C}$.

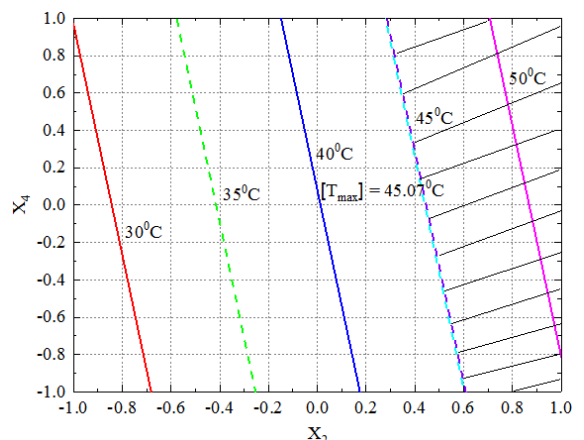

e) $\mathrm{X}_{2}\left(\mathrm{Q}_{\max }\right)=(120-350) \mathrm{kJ} / \mathrm{kg}, \mathrm{X}_{4}\left(\mathrm{t}_{\mathrm{w}}\right)=(8-16)^{\circ} \mathrm{C}$.

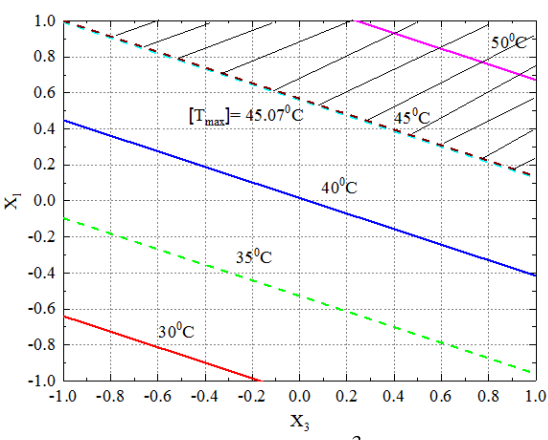

b) $X_{1}(C)=(200-450) \mathrm{kg} / \mathrm{m}^{3}, X_{3}\left(t_{\mathrm{pl}}\right)=(10-$ $25)^{\circ} \mathrm{C}$.

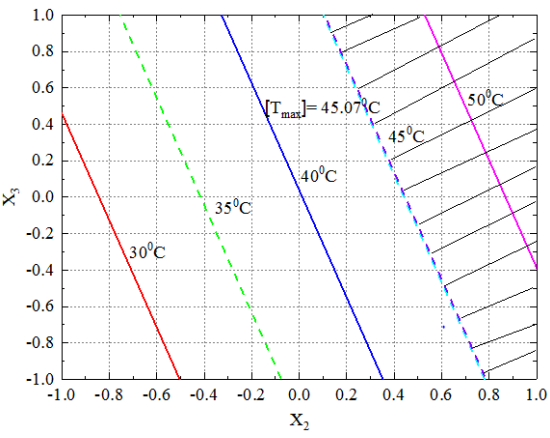

d) $X_{2}\left(Q_{\max }\right)=(120-350) \mathrm{kJ} / \mathrm{kg}, X_{3}\left(\mathrm{t}_{\mathrm{pl}}\right)=(10-$ $25)^{\circ} \mathrm{C}$.

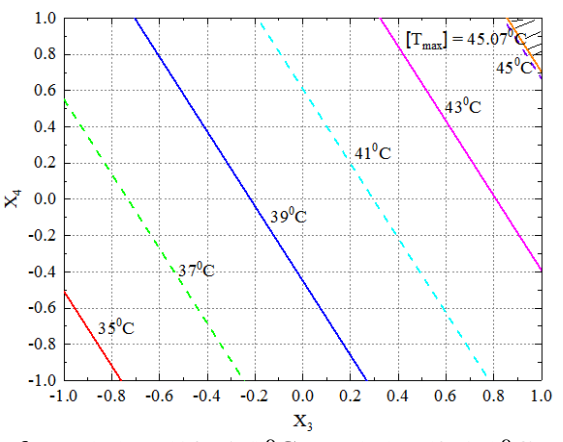

f) $\mathrm{X}_{3}\left(\mathrm{t}_{\mathrm{pl}}\right)=(10-25)^{\circ} \mathrm{C}, \mathrm{X}_{4}\left(\mathrm{t}_{\mathrm{w}}\right)=(8-16)^{\circ} \mathrm{C}$.

Fig. 2. Nomograms in order to determine the maximum temperature of the concrete structure 
Considered an option in the center with factors: $\mathrm{x}_{1}=0, \mathrm{x}_{2}=0, \mathrm{x}_{3}=0$ and $\mathrm{x}_{4}=0(\mathrm{C}=325$ $\mathrm{kg} / \mathrm{m}^{3}, \mathrm{Q}_{\max }=235 \mathrm{~kJ} / \mathrm{kg}, \mathrm{t}_{\mathrm{pl}}=17.5^{\circ} \mathrm{C}$ and $\left.\mathrm{t}_{\mathrm{w}}=12^{\circ} \mathrm{C}\right)$. Using the Midas Civil computer program, the maximum temperature in the concrete mass was determined, equal to $\mathrm{T}_{\max }=$ $39.5^{\circ} \mathrm{C}$. The error of the result obtained by the nomograms in Figure 2 compared to the result analyzed by the Midas Civil program $(0.87 \%)$, which can be accepted as a satisfactory value from equation (11).

The results of the analysis of the temperature field of two variants of concrete structures: with cooling pipe systems $\left(\mathrm{C}=325 \mathrm{~kg} / \mathrm{m}^{3}, \mathrm{Q}_{\max }\right.$ $=235 \mathrm{~kJ} / \mathrm{kg}, \mathrm{t}_{\mathrm{pl}}=17.5^{\circ} \mathrm{C}, \mathrm{t}_{\mathrm{w}}=$ $12^{\circ} \mathrm{C}$ ) and without cooling pipe systems $\left(\mathrm{C}=325 \mathrm{~kg} / \mathrm{m}^{3}\right.$, $\mathrm{Q}_{\max }=235 \mathrm{~kJ} / \mathrm{kg}, \mathrm{t}_{\mathrm{pl}}=17.5^{\circ} \mathrm{C}$ ) concrete massifs are shown in Figures 3 - 4.

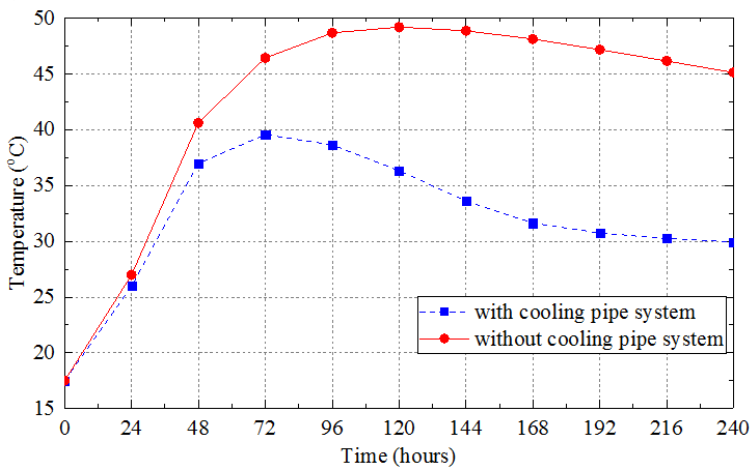

Fig. 3. Temperature graph in the center of the concrete mass over time
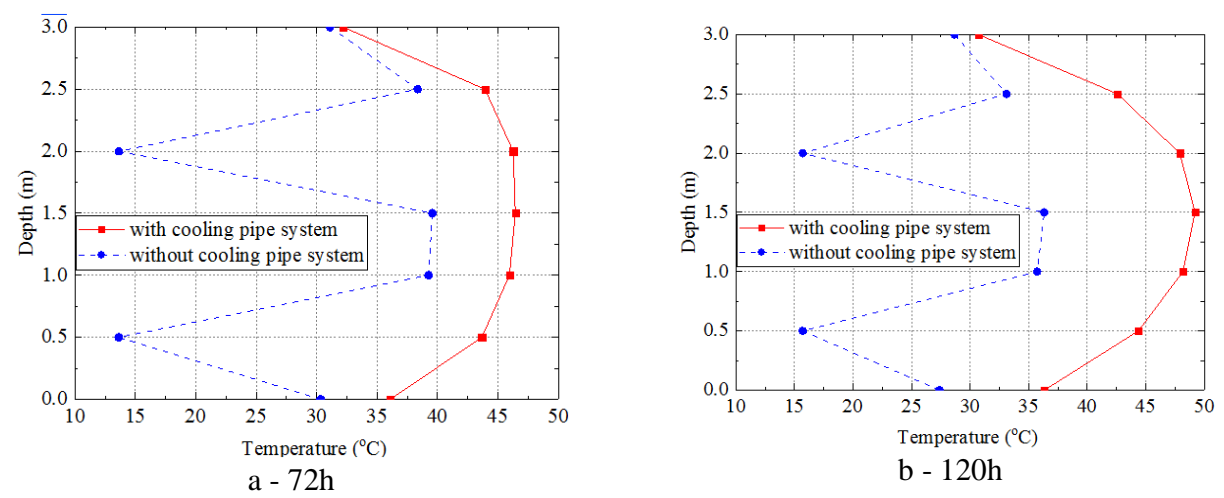

Fig. 4. Temperature profile of concrete in the centre of the cross section of the concrete mass

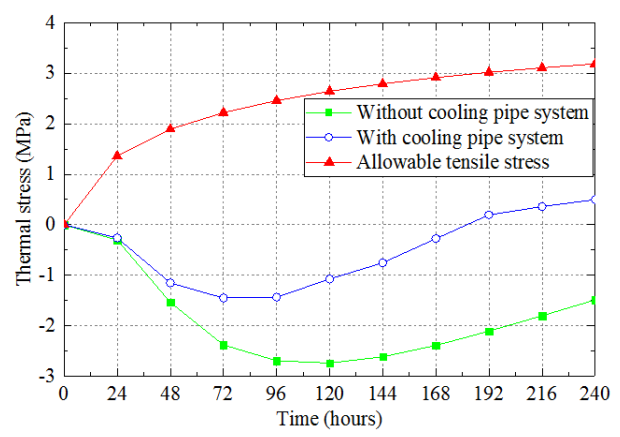

a - node 282 - center

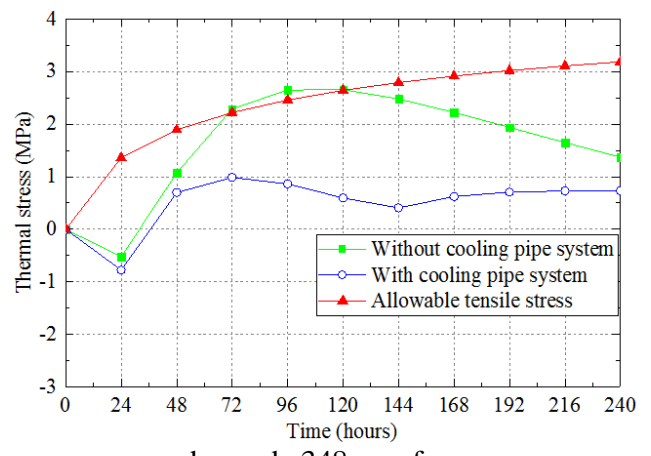

b - node 348 - surface

Fig. 5. Changes in the thermally stressed state over time

Figures 3 - 4 are shows that the temperature profiles shown in depth over time. It can be seen that reducing the temperature by cooling the pipe is effective. For a more detailed analysis of the thermally stressed state, the obtained values are presented for two selected 
nodes. Changes in the thermally stressed state with time in the selected nodes are shown in Figure 5.

When the concrete mass without the cooling pipe system, thermal stress at the surface of concrete mass (node 348) exceeds allowable stress for 72 hours and cracks are formed. With thermal stress at the center of concrete mass (node 282) with pipe cooling system is less than the allowable thermal stress. So, cracks in the concrete are not formed.

\section{Conclusions}

Based on the results of the studies, the following conclusions:

1. The result of the mathematical model can be used to determine the maximum temperature of the concrete mass as well as to control the maximum temperature so that can prevent thermal cracking in the concrete mass during construction of concrete structures, such as a dam, bridge, foundation, etc.

2. When a concrete mass with the cooling pipe system the maximum temperature and temperature drop between the centre and the outside in the concrete mass are significantly reduced. The maximum temperature and temperature difference of the concrete mass depends on the distribution of the cooling pipe system.

3. The research results are reference materials for construction projects, such as a dam, foundation, foundation, etc with the cooling pipe system.

This research was financially supported by Moscow State University of Civil Engineering. Conflict of interest on behalf of all authors, the corresponding author states that there is no conflict of interest.

\section{References}

1. ACI Committee 207. ACI 207.1R-05: Guide to Mass Concrete (ACI Manual of Concrete Practice, Part 1, America, 2005)

2. Korea Concrete Institute. Thermal crack control of mass concrete (Manual, 2010)

3. K. Vladan, S. Ljubodrag, M. Nikola, Fac. of Mech. Eng. 43 (2015)

4. M.N. Kamran, Mass concrete dams (Adv. Construc. Tech., Univer. of Wash. 2016)

5. N. Aniskin, N.T. Chuc and H.Q. Long, MATEC Web of Conf. 251, 02014 (2018) (https://doi.org/10.1051/matecconf/201825102014)

6. A.I. Husein Malkawi, M. Aufleger, T. Strobl, M. Conrad, S. Mutasher and M. AlJammal, Inter. J. on Hydro. \& Dams 11, 4 (2004)

7. E. Rana, E. Ayma, M. Charles, IABSE Confer. - Struc. Eng.: Pro. Solu. to Glob. Chall., Geneva, Switzerland (2015)

8. B. Kuriakose, B. Nageswara Rao, G.R. Dodagoudar, Glob. Colloq. in Re. Adv. and Effec. Resear. in Eng., Sci. and Tech. 25 (2016)

9. N. Aniskin, N.T. Chuc. IOP Conf. Series: Mater. Sci. and Eng. 365 (2018) 042083 (https://doi.org/10.1088/1757-899X/365/4/042083)

10. K.V. Shchurin and D.A. Kosykh, Methods and practice of planning and organizing the experiment Orenburg (2012)

11. N. Aniskin, N.T. Chuc, MATEC Web of Confer. 196, 04059 (2018) (https://doi.org/10.1051/matecconf/201819604059)

12. Y.P. Adler, Planning an experiment when searching for optimal conditions (Moscow, 1976)

13. T.G. Myers, N.D. Fowkes, and Y. Ballim, J. of Eng. Mech. 135, 12 (2009) 
14. R.S. Piyius and C.R. Durgesh, J. of Eng. Mech. 144, 3 (2018)

15. D. Jianxin, C. Shenghong. App. Ther. Eng. 61 (2013)

16. Q. Yongrong and Z. Guoxin, Adv. in Mech. Eng. 9, 2 (2017)

17. L. Bingqi, W. Zhenhong, J. Yunhui and Z. Zhenyang, Adv. in Mech. Eng. 10, 1 (2018)

18. A.V. Bushmanova, N.V. Videnkov, K.V. Semenov, G. Barabanshchikov Yu, A.V. Dernakova, V.K. Korovina, Magaz. of Civ. Eng. 3 (2017)

19. N.A. Aniskin, N.T. Chuc, A.B. Ilya, D.H. Hung, Vestnik MGSU 13, 11 (2018) (https://doi.org/10.22227/1997-0935.2018.11.1407-1418)

20. N.A. Aniskin, Nguyen Hoang, Vestnik MGSU 8 (2014)

21. V.I. Teleshev, N.I. Vatin, A.N.Marchuk, M.V. Komarinsky. (Pub: Moscow, 2012) 